\title{
Analysis of Overcurrent Safety in Miniature Circuit Breaker with Alternating Current
}

\author{
Jamaaluddin Jamaaluddin*, Izza Anshory, Shazana Dhiya Ayuni \\ Department of Electrical Engineering, Faculty of Science and Technology, \\ Universitas Muhammadiyah Sidoarjo, Sidoarjo, East Java, Indonesia \\ *Corresponding author, e-mail: jamaaluddin@umsida.ac.id
}

\begin{abstract}
In the utilization of solar energy, the equipment used includes Photovoltaic Cells, solar charging controls, batteries, protection devices, and other measuring devices. This solar power generation system is the name of a system that can convert solar energy into electric power. This solar power plant used in buildings is referred to as the Solar Building System (SBS). To perfect this solar power generation system, it is necessary to manage the electric power protection system. The protection system in this solar power plant includes the use of Miniature Circuit Breakers $(M C B)$. This Miniature Circuit Breaker is a tool for overcurrent protection in alternating current systems and direct current systems. In order to obtain a good protection system for this solar power plant, a study was conducted on the use of a miniature circuit breaker that is effective for a certain type of current. The research method used is the use of alternating current and direct current miniature circuit breakers in alternating current circuits. Observations and recordings were carried out, so that the obtained results were quite significantly different in their use. From the results of the study, it was found that the Miniature alternating current circuit breaker has better characteristics in alternating current circuits, when compared to direct current miniature circuit breakers.
\end{abstract}

Keywords: Solar Building System (SBS); Miniature Circuit Breaker (MCB); Solar Power Plant.

\section{Introduction}

In the last decade or so, humans have a very large need for electrical energy. The need for electricity is a great human need in carrying out their lives. From the moment you wake up until you go back to sleep, all human life is related to electricity. Even how much electricity is used in a country is one indicator of the nation's development. To generate electrical energy currently still using fossil energy. This fossil energy occupies the largest portion of electricity generation in Indonesia. Meanwhile, the utilization of new and renewable energy is still very minimal. Especially when it comes to solar energy. The average annual growth of electrical energy in Indonesia is $4.7 \%$ per year during 2011-2030[1]-[3].

In Indonesia, the country has large potential of renewable energy resources, namely solar power, wind power and hydro power. In this study, solar power is discussed on its potential, characteristics, and energy generation. For Indonesia's potential for solar power, Indonesia has the potential for solar radiation with an average of $4.8 \mathrm{kWh} / \mathrm{m} 2 /$ day [4][6]. From this potential, solar radiation can be converted into electricity. The advantages of solar power are almost zero emissions so that the air is not polluted, noiseless pollution. However, in terms of the characteristics of energy changes and the high investment costs of solar power plants, more indepth research is still needed. Also, in Universitas Muhammadiyah Sidoarjo environment, in-depth exploration and research are still being carried out on its application. So that this solar power plant is an alternative source of electricity in addition to fossil-based power plant managed by PLN (Indonesia state-owned Electricity Company) [5], [7].

The reliability of photovoltaic is on solar irradiance and photovoltaic surface temperature. The two must go hand in hand. Irradiance is good, but when the temperature is too cold or too hot, it will cause the photovoltaic current and voltage performance. The two things above are closely related to the climate or weather in an area. 
Understanding the area by conducting a feasibility study is very necessary[8][5][4][9].

This study explains how to carry out protection management on solar power plants in this electrical engineering laboratory. The protection management in question is how to manage the use of Miniature Circuit Breakers $(M C B)[10]-[12]$.

In $M C B$, several characteristics related to its operation need to be studied. Moreover, it is related to the installation of $M C B$ in the solar power generation system. Where the $M C B$ will be installed on alternating current and direct current. This is because the solar power generation system is powered by alternating current and direct current. $M C B$ management is needed to get a reliable protection system. The installation of this solar power generation system starts from a laboratory to a building. The use of solar power in a building is called the Solar Building System(SBS)[13][14].

\section{Material and Metods}

\section{II.1. Flowchart of Methods}

Flow chart of this metdho as shown in Fig. 1.

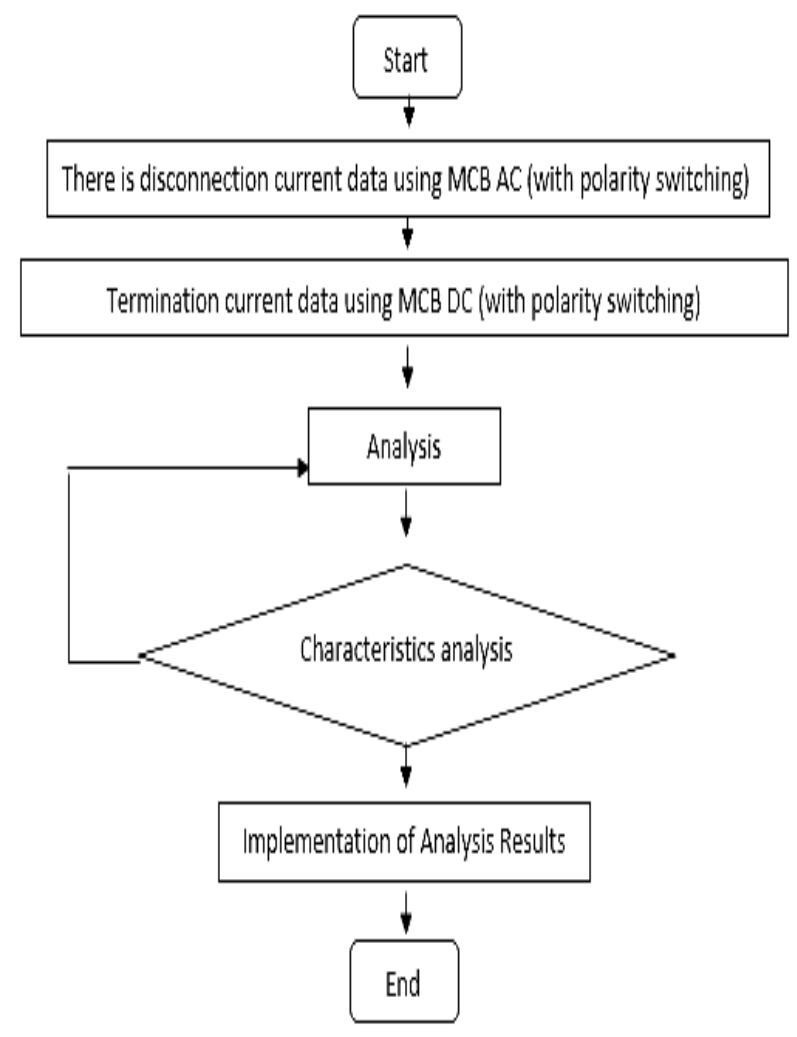

Fig. 1. Methods Research Flow Chart

\section{II.2. Research Stages}

This research activity was carried out in the following stages (see Fig. 1). Photovoltaic installation, solar charger controller installi 69 accu (battery), protection devices and sy measuring devices. The simulation was conducted using a Sub Distribution panel device at the Electrical Engineering Laboratory. Installation of alternating current and direct current $M C B$ s were connected to an alternating current circuit. Then observations, recording, analysis, and reporting were completed.

\section{II.3. Data collection technique}

The actions taken in the implementation of this research were: Installing a $D C M C B$ and running alternating current. Measurement of the voltage and current cut off. After that, the $M C B$ input and output polarity was reversed, and the voltage and current were measured. The next step was to install an $A C$ $M C B$ and alternating current. Measurement of the voltage and current cut off. After that, the $M C B$ input and output polarity was reversed and the voltage and current were measured.

\section{Result and Discussion}

\section{III.1. Block Circuit Diagram}

The research was carried out as shown in the block diagram in Figure 2. In Figure 2, you can see the sequence of processes in the Solar Power Generation system. Starting from Photovoltaic, capturing sunlight enters the Solar Charge controlled and the current is divided into 2, namely entering the accu and entering the inverter. $M C B$ installation is done after the inverter which has an alternating current flow continues to the load (Fig. $3)$.

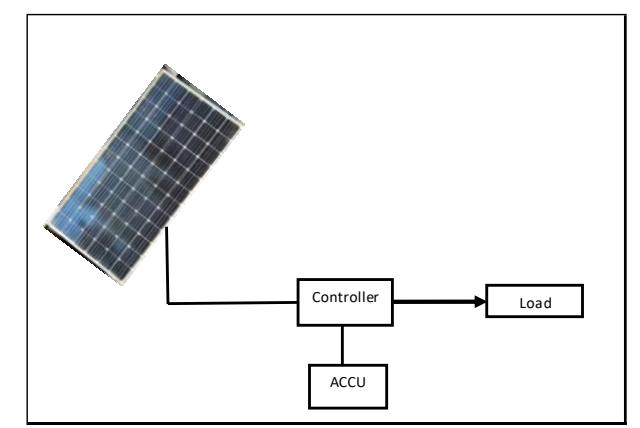

Fig. 2. Solar Power Plant System Block Diagram 
The implementation of this research uses the circuit as shown in Figure 3. Measurement of the disconnection voltage and current on the $M C B$ which is installed in an alternating current circuit, is carried out when the disconnection occurs until the termination occurs. This research also observes the breaking voltage and current if the $M C B$ polarity is reversed.

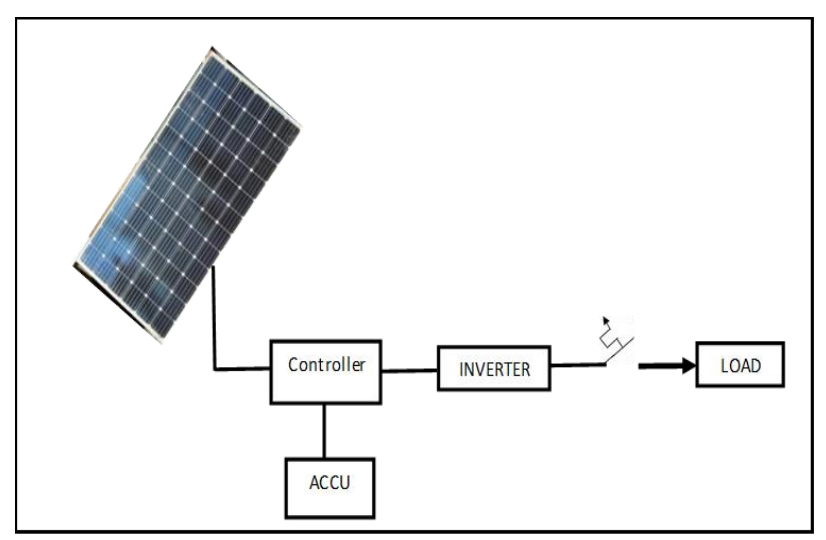

Fig. 3. Measurement $A C$ And $D C M C B$ Testing Using $A C$ Currents

\section{II.2. Components and Circuits Used}

This study uses several components, namely: Photovoltaic, Solar charge controlled, Accumulator, protection devices and measuring instruments. Where each of the components mentioned above can be seen in Fig. 4 to 7. In Fig. 4, you can see Photovoltaic which functions to convert solar energy into electrical energy.

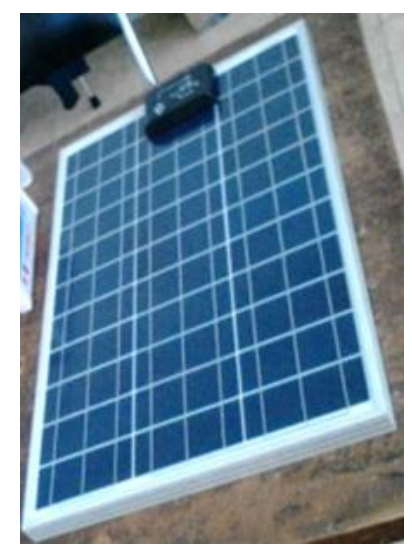

Fig. 4. Photovoltaic

Fig.4 shows type photovoltaic use in this resarch. The type photovoltaic is polycristaline. That type has a random crystal arrangenment because it is manufactured by casting process. This type requires more surface area than the monocrystal type to produce the same electrical power.

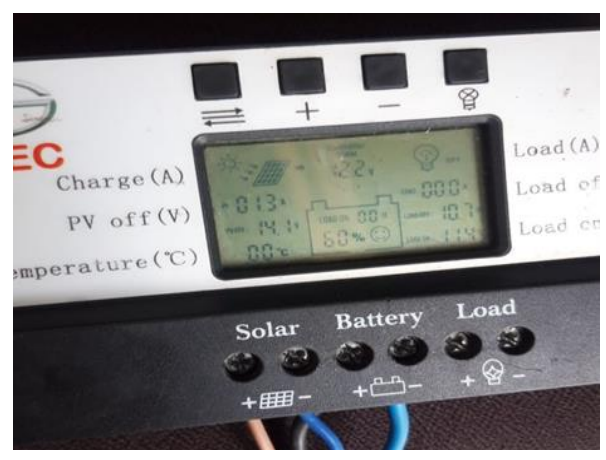

Fig. 5. Solar Charge Controlled (SCC)

Figure 5 shows the Solar Charge Controller $(S C C)$. The function of this $S C C$ is to regulate the maximum voltage and current from the PV that can enter the system. Likewise, setting the amount of voltage and current that goes into the battery. SCC consists of two types, namely type $P W M$ (Pulse width modulation) and Type MPPT (Maximum Power Point Tracking). While in this research used $P W M$ type.

In addition to the $P V$ and $S C C$ above, there are also measurement and protective equipment used, namely the $A C M C B$ as shown in Figure 6. And the $D C M C B$ as shown in Figure 7. On the side of each $M C B$, there is a measuring device. The measuring instrument in question is also of the type of alternating current and direct current, according to use during research.

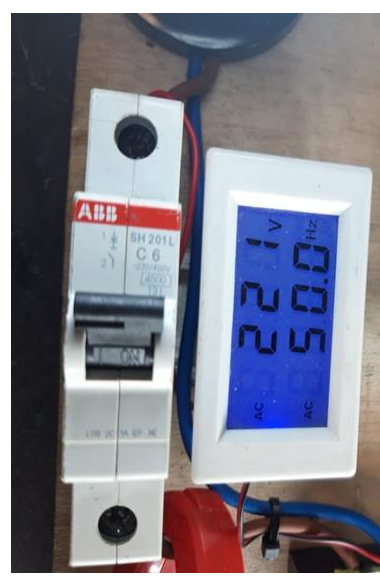

Fig. 6. $A C M C B$ With Voltage And Current Meters

Fig. 6. shows $A C M C B$ using the $A B B$ brand which will disconnect the current at $6 \mathrm{~A}$. Beside the $M C B$, there is a measurement device for alernating current and voltage. This tool is installed to 
determine the movement of current and voltage when a disconection occurs.

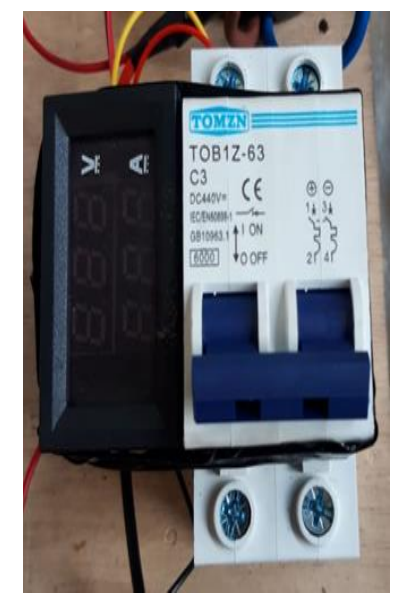

Fig. 7. $D C M C B$ With Voltmeter And Amperemeters

Fig. 7. shows $D C M C B$ from TOMZN brand with disconnecting current of $3 \mathrm{~A}$. Beside the $M C B$, there is a measurement device for direct current and voltage. This tool is installed to determine the movement of current and voltage when a disconnection occurs.

The complete series of components for the implementation of this research can be seen in Figure 8 . Figure 8 shows the $S C C$, accu, inverter, $A C M C B$ and $D C M C B$ which are operated alternately on alternating current output of the inverter. While the load is installed lights and other electrical loads to achieve the disconnection current.

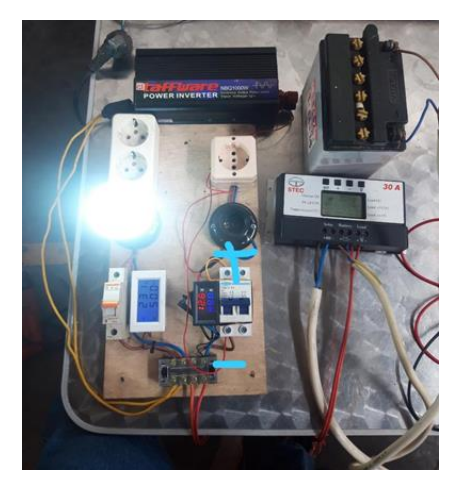

Fig. 8. Test circuit using $D C M C B$ and $A C M C B$ with Voltampere and Amperemeters

\section{III.3. Measurements Taken}

Measurement tools in this study are using a voltmeter and $A C$ ampere meter on the output side of the inverter. While the $M C B$ is carried out alternately using $A C M C B$ and $D C M C B$. By giving 2 different treatments by flipping the polarity of the $M C B$ input output, both $D C M C B$ and $A C M C B$. The measurement results can be seen in Table $1-4$.

TABLE 1

$A C M C B$ MEASUREMENT With $A C$ LoAd InPut Below $A C M C B$ AND OUTPUT ABOvE

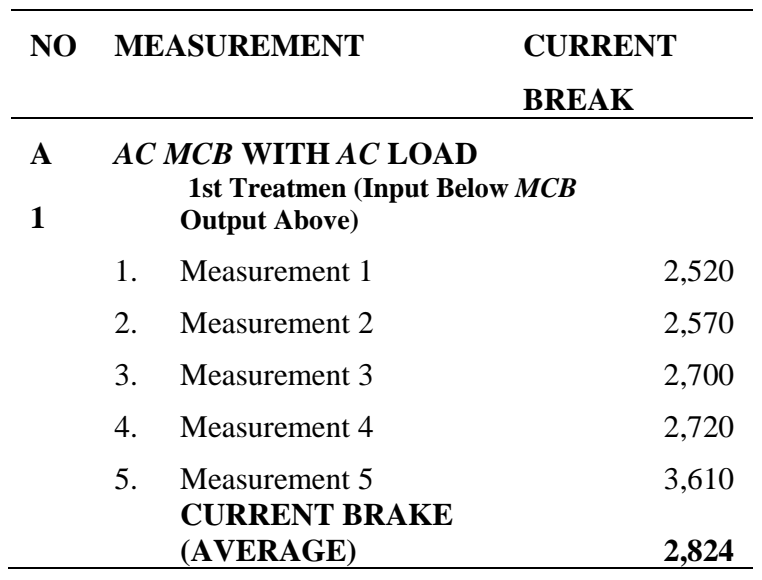

It can be seen in table 1, which is the result of measuring the disconnection current on the $A C$ $M C B$ with the input below $M C B$ and the output above $M C B$. In the measurement results, it can be seen that the average measurement results are: $2.824 \mathrm{~A}$.

TABLE 2

$A C M C B$ Measurement with $A C$ Load InPut Above $A C$ $M C B$ AND OUTPUT BELOW

\begin{tabular}{|c|c|c|}
\hline NO & MEASUREMENT & $\begin{array}{l}\text { CURRENT } \\
\text { BREAK }\end{array}$ \\
\hline B & $\begin{array}{l}A C M C B A C \text { LOAD } \\
2 \text { nd Treatmen (Input } \\
\text { Output Below } M C B \text { ) }\end{array}$ & Above \\
\hline & 1. Measurement 1 & 3,360 \\
\hline & 2. Measurement 2 & 2,830 \\
\hline & 3. Measurement 3 & 2,890 \\
\hline & 4. Measurement 4 & 4,040 \\
\hline & $\begin{array}{ll}\text { 5. } & \text { Measurement } 5 \\
\text { CURRENT BRAKE } \\
\text { (AVERAGE) }\end{array}$ & $\begin{array}{l}2,640 \\
\mathbf{3 , 1 5 2}\end{array}$ \\
\hline
\end{tabular}

In table 2, it can be seen that the results of the disconnection measurement using an $A C M C B$ with an alternating current load with the input polarity position above the $M C B$ and the output polarity below the $M C B$. The average result of the disconnection measurement shows a value of 3.152 A. 
TABLE 3

Measurement of $D C M C B A C$ LOAD InPut Below $D C M C B$ AND OUTPUT ABOve

\begin{tabular}{|c|c|c|}
\hline NO & MEASUREMENT & $\begin{array}{l}\text { CURRENT } \\
\text { BREAK }\end{array}$ \\
\hline $\mathbf{C}$ & \multicolumn{2}{|c|}{$\begin{array}{l}D C M C B A C \text { LOAD } \\
\text { 1st Treatmen (Input Below } M C B \\
\text { Output Above) }\end{array}$} \\
\hline & 1. Measurement 1 & 8,680 \\
\hline & 2. Measurement 2 & 8,540 \\
\hline & 3. Measurement 3 & 8,560 \\
\hline & 4. Measurement 4 & 8,570 \\
\hline & 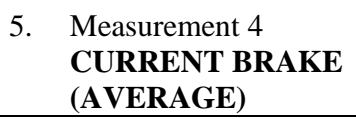 & $\begin{array}{l}8,590 \\
\mathbf{8 , 5 8 8}\end{array}$ \\
\hline
\end{tabular}

In table 3 , it can be seen that the results of the current cut off measurement on a $D C M C B$ with an alternating current load, with the input at the bottom of the $M C B$ and the output at the top of the $M C B$. The measurement results have an average value of $8,588 \mathrm{~A}$.

TABLE 4

Measurement of $D C M C B A C$ load InPut Above $D C$ $M C B$ AND OUTPUT BELOW

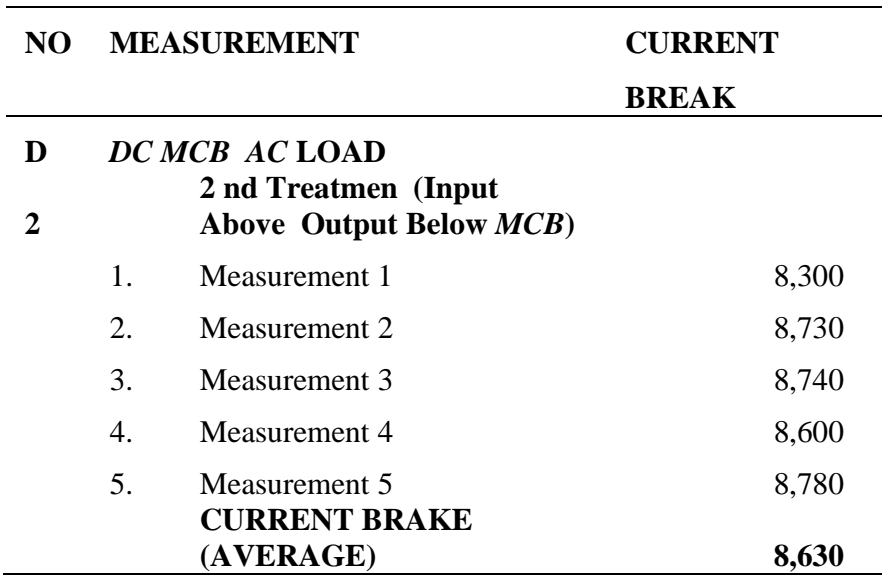

In table 4 , it can be seen the results of the current cut off measurement on a $D C M C B$ with an alternating current load, with the input at the top of the $M C B$ and the output at the bottom of the $M C B$. The measurement results have an average value of $8,63 \mathrm{~A}$.

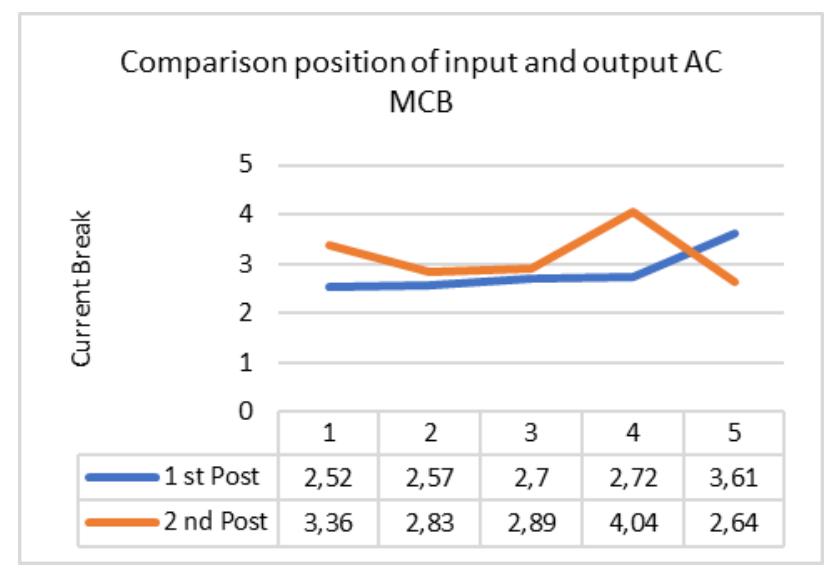

Fig. 9. Graph Of The Comparison Of The Input And Output Positions Reversed On The $A C M C B$ With The $A C$ Load

From Table 1 to Table 4, an illustration is obtained in Fig. 9 and 10. The first position shows that the input position is below the output position , while the second position shows the input position is upper the output position. Installed $A C M C B$ loads use $A C$ current. Fig. 9 shows that the first position has a more stable result in the process of breaking its current. Meanwhile, the second position shows that the cut-out current is more unstable due to fluctuating changes in the same conditions as the first position.

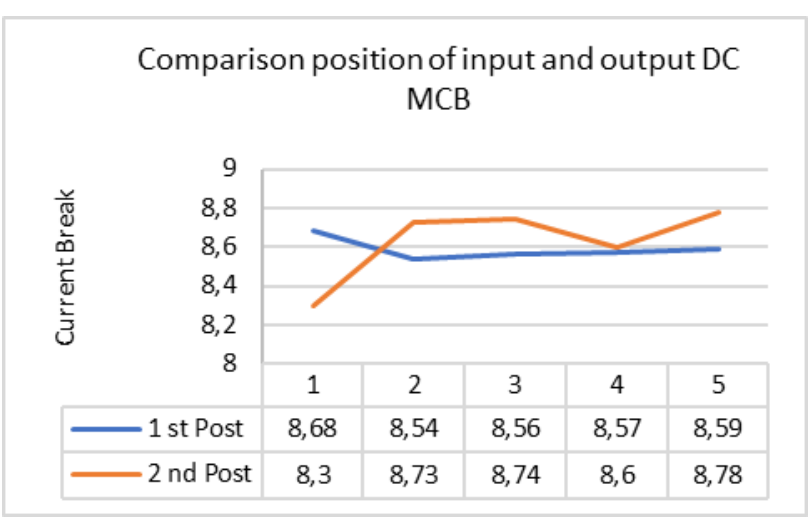

Fig. 10. Graph Of The Comparison Of The Input And Output Positions Reversed On DC MCB With $A C$ Load

The first position shows that the input position is below the output position, while the second position shows the input position is upper the output position. Installed $D C M C B$ loads use AC current.. Fig. 10 shown that the first position has a more stable result in the process of breaking its current. Meanwhile, the second position shows that the cut- 
out current is more unstable due to fluctuating changes in the same conditions at the first position.

\section{Conclusion}

From the results of the research above, it can be concluded that the use of an $M C B$ that is in accordance with the current flowing has a more precise current-breaking value. $A C$ current will be precision safety when using an $A C M C B$.

As for determining the polarity of the input output on the $M C B$, it has the following results: the input at the bottom has a better security value than if the input is placed at the top.

\section{ACKNOWLEDGEMENTS}

We express our deepest gratitude to the DRPM (Direktorat Riset dan Pengabdian Masyarakat) of the Universitas Muhammadiyah Sidoarjo which has helped both morally and materially for the realization of this paper. May Allah reward you with more goodness.

\section{References}

[1] M. Bortolini, M. Gamberi, and A. Graziani, "Technical and economic design of photovoltaic and battery energy storage system," Energy Convers. Manag., vol. 86, pp. 81-92, 2014.

[2] Jamaaluddin, I. Robandi, I. Anshory, Mahfudz, and R. Rahim, "Application of interval type-2 fuzzy inference system and big bang big crunch algorithm in short term load forecasting new year holiday," J. Adv. Res. Dyn. Control Syst., 2020.

[3] Jamaaluddin, I. Robandi, and I. Anshory, "A very short-term load forecasting in time of peak loads using interval type- 2 fuzzy inference system: A case study on java bali electrical system," J. Eng. Sci. Technol., vol. 14, no. 1, pp. 464-478, 2019.

[4] A. Supriyadi, J. Jamaaluddin, T. Elektro, and U. Muhammadiyah, "Analisa Efisiensi Penjejak Sinar Matahari Dengan Menggunakan," Jeee-U, vol. 2, no. APRIL, 2018, pp. 8-15, 2018.

[5] B. P. dan P. T. I. Penelitian, Outlook Energi Indonesia 2013. 2013.

[6] M. Muchlis and A. D. Permana, "Proyeksi Kebutuhan Listrik PLN 2003 s.d. 2020,” Pengemb. Sist. Kelistrikan dan Menunjang Pembang. Nas. Jangka Panjang, p. 11 Halaman, 2003.

[7] California Energy Commission, "A guide to photovoltaic system design and installation," Calif. Energy Comm., no. June, p. 39, 2001.

[8] B. García-Domingo, M. Torres-Ramírez, J. De
La Casa, J. Aguilera, and F. J. Terrados, “Design of the back-up system in Patio 2.12 photovoltaic installation," Energy Build., vol. 83, pp. 130139, 2014.

[9] Sekretariat Perusahaan PT. PLN, "Statistik PLN 2014," no. 02701, p. iv, 2015.

[10] Dickson Kho, "Pengertian MCB (Miniature Circuit Breaker) dan Prinsip kerjanya," Tek. Elektron., 2018.

[11] H. Pradika and M. Moediyono, "Thermal Overload Relay Sebagai Pengaman Overload Pada Miniatur Gardu Induk Berbasis Programmable Logic Controller (Plc) CpleE40dr-A," Gema Teknol., 2015.

[12] A. Goeritno and S. Pratama, "Rancang-Bangun Prototipe Sistem Kontrol Berbasis Programmable Logic Controller untuk Pengoperasian Miniatur Penyortiran Material," J. Rekayasa Elektr., 2020.

[13] S. Bartien, "Puil 2011," DirJen Ketenagalistrikan, 2011.

[14] Kementerian Energi dan Sumber Daya Mineral, Statistik ketenagalistrikan 2015. 2014.

\section{AUTHORS' INFORMATION}

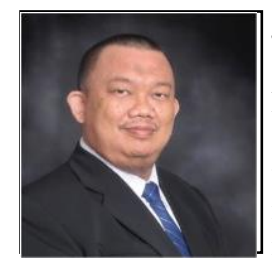

Jamaaluddin Jamaaluddin was born in Surabaya, October 17, 1970, and completed his doctoral education at ITS Surabaya in 2020. The research fields carried out are in the fields of power systems and artificial intelligent. Several scientific journal manuscripts have been published. he is a lecturer in the electrical engineering study program, Muhammadiyah University of Sidoarjo. East of Java Indonesia, became the head of the energy conversion and electric power engineering laboratory. He has an IEEE members and etc.

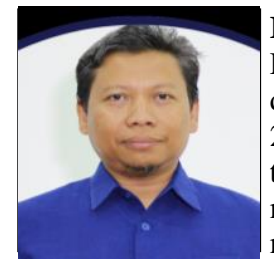
Izza Anshory was born in Surabaya, December 9, 1975, and completed his doctoral education at ITS Surabaya in 2021. The research fields carried out are in the fields of power systems and dinamika motor system. Several scientific journal manuscripts have been published. He is a lecturer in the electrical engineering study program, Muhammadiyah University of Sidoarjo. East of Java Indonesia, became the head of the Computer Communication laboratory. $\mathrm{He}$ has an IEEE members and etc.

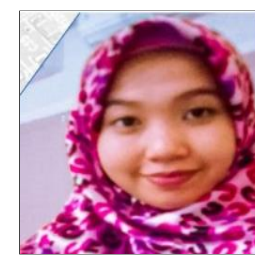

Shazana Dhiya Ayuni, was born in Surabaya, February 12, 1991, and completed her master degree at ITS Surabaya in 2020. The research fields carried out are in the fields of telecomunication and multimedia. Several scientific journal manuscripts have been published. She is a lecturer in the electrical engineering study program, Muhammadiyah University of Sidoarjo. East of Java Indonesia. 